\title{
Cosmetic Injection of Botulinum Toxin Unmasking Subclinical Myasthenia Gravis: A Case Report and Literature Review
}

\author{
Grégory Timmermans $^{a} \quad$ Frédérique Depierreux $^{\mathrm{a}} \quad$ François Wang $^{\mathrm{b}}$ \\ Isabelle Hansen ${ }^{\mathrm{a}}$ Pierre Maquet ${ }^{\mathrm{a}}$ \\ aDepartment of Neurology, University of Liège, CHU Sart-Tilman, Liège, Belgium; \\ ${ }^{b}$ Department of Neurophysiology, University of Liège, CHU Sart-Tilman, Liège, Belgium
}

\section{Keywords}

Botulinum toxin - Myasthenia gravis · latrogenic botulism · Single-fiber electromyography

\begin{abstract}
Cosmetic or therapeutic use of botulinum toxin type A (BoNT-A) is usually safe but can rarely cause iatrogenic botulism. latrogenic botulism and myasthenia gravis (MG) share similar clinical features, because both BoNT-A and anti-acetylcholine receptor antibodies impair neuromuscular transmission. We report a patient who underwent cosmetic BoNT-A injection and later developed serious local and systemic adverse reactions. The peculiarity of this case is that a latent seropositive MG was eventually discovered, suggesting that both iatrogenic botulism and MG contributed to the clinical picture. This patient is one of the less than 10 reported cases worldwide in whom MG was unmasked by BoNT-A injection. He is the first to be assessed in detail by single-fiber electromyography. This case emphasizes the risk associated with BoNTA injection in patients with subclinical impairment of neuromuscular transmission and prompts the search for MG in case of exaggerated response.

(C) 2019 The Author(s)

Published by S. Karger AG, Basel
\end{abstract}




\section{Case Reports in Neurology}

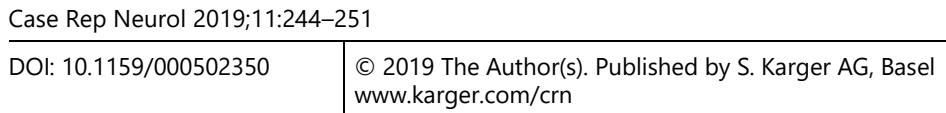

Timmermans et al.: Cosmetic Injection of Botulinum Toxin Unmasking Subclinical Myasthenia Gravis: A Case Report and Literature Review

\section{Introduction}

Local injection of botulinum toxin type A (BoNT-A) is frequently conducted for therapeutic or cosmetic purposes, and is most often safe. Possible complications are mainly related to local or systemic toxin diffusion. BoNT-A local spread to adjacent muscles is common and is generally transient. For instance, dysphagia is not rare after toxin injection for cervical dystonia, as well as eyelid ptosis after periocular injection. BoNT-A systemic diffusion can also occur but generally with no clinical consequences. Indeed, single-fiber electromyography studies have shown altered neuromuscular transmission in muscles distant from the injection site without any associated symptom [1, 2]. Nevertheless, in rare cases, systemic diffusion leads to clinical manifestations of variable severity (dysphagia, generalized muscular weakness, respiratory failure, ...) [3-5]. This condition, referred to as iatrogenic botulism, remains exceptional in healthy subjects and often results, at least in cosmetic cases, from inappropriate injections of unlicensed toxins in beauty salons [6]. By contrast, in patients with an underlying neuromuscular disease such as myasthenia gravis (MG), the potency of BoNT-A is increased, even at low dose. This increased sensitivity can be explained by synergistic effects of BoNT-A and MG on neuromuscular blockade. Here, we highlight this phenomenon by reporting a patient in whom BoNT-A administration unmasked subclinical MG.

\section{Case Report}

A 43-year-old man with unremarkable medical history and no chronic medication was admitted to the emergency department for bilateral eyelid ptosis and binocular diplopia gradually worsening for 10 days (Fig. 1). Symptoms were initially mild but progressed in a few days to nearly complete eyelid closure and external ophthalmoplegia. Six weeks before symptom onset, the patient had received cosmetic injection of abobotulinum toxin A (Azzalure ${ }^{\circledR}$; Galderma) to the glabellar, forehead, and lateral canthal rhytids (total of $84 \mathrm{U}$ in one session). A similar injection had been performed 2 years earlier with no adverse effect. Neurological examination was entirely normal apart from ocular signs. Conventional blood tests, cerebrospinal fluid analysis, and brain magnetic resonance imaging were normal. A first electroneuromyography (ENMG) showed normal parameters: normal nerve conduction velocities and latencies (fibular and sural nerves), normal amplitudes of the compound muscle action potential (CMAP), decremental responses $<10 \%$ during repetitive nerve stimulation (RNS) at $3 \mathrm{~Hz}$ of the facial nerves (nasalis, orbicularis oculi), right ulnar nerve (abductor digiti minimi), and radial nerve (anconeus). However, a single-fiber study (SFEMG) of the left orbicularis oculi showed major impairment of neuromuscular transmission (mean jitter of $112 \mu$ s with $50 \%$ blocking). Interestingly, in most neuromuscular junctions, jitter and blocking were greater with low discharge rates $(5 \mathrm{~Hz})$ than with high ones $(40 \mathrm{~Hz})$, suggesting a presynaptic disorder (Fig. 2). Based on these clinical and electrophysiological data, a local effect of BoNT-A was suspected. The patient was first treated with oral pyridostigmine $240 \mathrm{mg} /$ day, based on the intuition that it would help neuromuscular transmission, but to no avail. By contrast, subcutaneous neostigmine $0.25 \mathrm{mg}$ every $2 \mathrm{~h}$ was associated with a rapid but moderate clinical improvement. This treatment was nonetheless discontinued after a few days due significant bradycardia. Two weeks later, the patient experienced further clinical deterioration with 


\section{Case Reports in Neurology}

Case Rep Neurol 2019;11:244-251

DOI: $10.1159 / 000502350$

2019 The Author(s). Published by S. Karger AG, Basel www.karger.com/crn

Timmermans et al: Cosmetic Injection of Botulinum Toxin Unmasking Subclinical

Myasthenia Gravis: A Case Report and Literature Review

worsening of the eyelid ptosis, dysphagia, and subjective generalized weakness. Repetitive nerve stimulation at $3 \mathrm{~Hz}$ revealed, this time, decremental responses in all muscles tested (decrement in percentages of area: right nasalis 35\%, left nasalis 36\%, right trapezius $26 \%$, right anconeus $24 \%$, right abductor digiti minimi $29 \%$ ). Repair of decremental response was recorded in the right abductor digiti minimi ( 6 vs. 29\%) after 1 min of voluntary contraction, followed by a worsening of decremental response (37 vs. 29\%) $3 \mathrm{~min}$ after this effort, suggesting a postsynaptic disorder. Serum acetylcholine receptor antibodies (anti-AChR) were measured in the hypothesis of MG and went back strongly positive at $6.4 \mathrm{nmol} / \mathrm{L}$ (normal values $<0.5$ ), which was confirmed by a second test. Therefore, the simultaneous diagnosis of MG was established. Computed tomography of the chest showed no thymoma. Pyridostigmine treatment was gradually resumed (without significant bradycardia) in combination with oral methylprednisolone $1 \mathrm{mg} / \mathrm{kg}$. Slowly progressive clinical improvement was then observed; dysphagia and generalized weakness completely resolved in 4 weeks, while moderate ptosis and ophthalmoparesis persisted for more than 6 months.

\section{Discussion}

To our knowledge, this patient is the 8th case reported in the literature of latent MG, revealed by BoNT-A injection [7-14], and the most documented case from an electrophysiological point of view. These different cases are listed in Table 1. It should be noted that 7 other cases of BoNT-A injection have been reported in patients with already diagnosed myasthenia [15-21].

BoNT-A inhibits presynaptic release of acetylcholine at the neuromuscular junction, whereas MG antibodies block acetylcholine receptors on the postsynaptic side. The combination of the two mechanisms has therefore synergistic detrimental effect on neuromuscular transmission. This phenomenon probably explains the clinical manifestations observed in our patient. In this case, the purely ocular and steady (i.e., nonfluctuating) nature of the initial symptoms as well as the history of recent periocular BoNT-A injection strongly suggested a local action of BoNT-A. However, the subsequent occurrence of clinical deterioration associated with dysphagia and generalized weakness could not be explained by the local effect of the toxin alone and suggested the existence of a systemic process related to the toxin itself (iatrogenic botulism) or to a neuromuscular disorder, or both. The presence of AChR antibodies, the partial response to neostigmine, and the highly suggestive electrophysiological picture eventually led to the diagnosis of MG. We surmise that MG was latent, and that BoNT-A injection brought it to the symptomatic threshold by its usually subclinical action on neuromuscular junction in both local and remote muscles. In other words, neuromuscular transmission, already jeopardized on its postsynaptic side by subclinical effects of anti-AChR antibodies, eventually failed when the toxin disturbed its presynaptic component.

Our patient experienced an unusually long delay between BoNT-A injection and symptom onset (about 6 weeks). This contrasts with the other reported cases whose latency period ranged from 1 to 36 days [6]. We do not know the reason for this delayed course. Another interesting aspect is the history of a previous injection session, 2 years earlier, without adverse event. This feature is actually observed in other cases of iatrogenic botulism (with or without MG), where complications only occur after several injection sessions [5, 8, 13, 22]. 


\section{Case Reports in Neurology}

Case Rep Neurol 2019;11:244-251

DOI: $10.1159 / 000502350$

(C) 2019 The Author(s). Published by S. Karger AG, Basel www.karger.com/crn

Timmermans et al.: Cosmetic Injection of Botulinum Toxin Unmasking Subclinical

Myasthenia Gravis: A Case Report and Literature Review

One possible explanation might be that toxin spread is highly unpredictable and varies substantially from one injection to another. Finally, it should be stressed that our patient suffered from significant complications despite the use of usual BoNT-A doses. Similar findings have been observed in previously reported cases, with doses as low as $12 \mathrm{U}$ sufficient to trigger symptoms [15]. This highlights the increased sensitivity of patients with neuromuscular disease to the effects of BoNT-A. It should be noted, however, that other patients with MG have been successfully treated with BoNT-A without complications $[16,17,19]$.

Electrophysiological assessment is of particular interest in this case because it combines signs of pre- and postsynaptic involvement. The expected electrophysiologic findings in human botulism are a reduction of CMAP amplitude, an incremental response of CMAP to highrate RNS or voluntary contraction (postactivation facilitation), a moderate and inconstant decremental response to slow-rate RNS, the absence of postactivation exhaustion, and a "myogenic" pattern on needle-EMG [23-25]. It is worthy of note that these data come mainly from studies of foodborne and infant botulism rather than iatrogenic botulism. In MG, the classical electrical features are a decremental response of CMAP to slow-rate RNS, a repair of the decrement immediately after 1 min of voluntary exercise followed by a worsening of the decrement 3-4 min post exercise (postactivation exhaustion) [26]. Single-fiber EMG is virtually always abnormal in both botulism and MG (increased jitter with frequent impulse blocking) and is therefore not a discriminating test unless the discharge rate is modified [27] (see below). In this patient, the typical features of MG were found with RNS, but not those of botulism. Indeed, neither reduced CMAP amplitude nor increment have been observed (the latter may arise from the former). This does not rule out, however, the existence of botulism, since conventional EMG can remain normal in mild cases of botulism, especially in iatrogenic ones [5, 22, $28,29]$. In our patient, electrical evidence of a partly presynaptic involvement was provided only by SFEMG: jitter decreased with higher discharge rates, which is equivalent to postactivation facilitation during high-rate RNS. This effect of firing rate is suggestive of a presynaptic blockade and is usually not seen in isolated MG, where, on the contrary, jitter decreases with slower discharge rates [23-25, 27, 30]. Overall, the electrophysiological abnormalities encountered in our patient combined features of pre- and postsynaptic dysfunction of neuromuscular transmission.

\section{Conclusion}

The synergistic effects of MG and BoNT-A explain why patients with an underlying neuromuscular disease have an increased risk of adverse reaction after BoNT-A injection. In patients with known neuromuscular disease or obvious clinical signs (e.g., dysphagia), caution is advised and BoNT-A should be either avoided or used sparingly if there is no therapeutic alternative. By contrast, there is no practical way to identify patients with latent, subclinical neuromuscular junction abnormalities before BoNT-A administration. Indeed, screening for neuromuscular disorder through anti-AChR antibodies or EMG testing is not conceivable. Thus, a complete patient history and physical examination must be conducted before BoNT-A injection, seeking any clinical data suggestive of latent MG. If the patient presents an exaggerated response to BoNT-A, especially if he responds to acetylcholinesterase inhibitors, MG 
should be considered before any further injection. Finally, an uncomplicated prior injection does not guarantee the absence of side effects after subsequent injections, even at low doses.

\section{Statement of Ethics}

The authors have no ethical conflicts to disclose. Informed consent for patient information and images to be published was provided by the patient.

\section{Disclosure Statement}

The authors have no conflicts of interest to declare.

\section{Funding Sources}

The authors received no funding support for the publication of this case report.

\section{Author Contributions}

Each author contributed to the treatment of the patient and diagnosis of the disease.

\section{References}

1 Singer C, Weiner WJ, Lange DJ, Brain MF, Greene P, Lovelace RE, et al. Letters to the editor. Muscle Nerve. 1993;16(6):677-82.

2 Garner CG, Straube A, Witt TN, Gasser T, Oertel WH. Time course of distant effects of local injections of botulinum toxin. Mov Disord. 1993;8(1):33-7.

3 Coban A, Matur Z, Hanagasi HA, Parman Y. Iatrogenic botulism after botulinum toxin type A injections. Clin Neuropharmacol. 2010 May;33(3):158-60.

4 Ghasemi M, Norouzi R, Salari M, Asadi B. Iatrogenic botulism after the therapeutic use of botulinum toxin-A: a case report and review of the literature. Clin Neuropharmacol. 2012 Sep-Oct;35(5):254-7.

5 Bhatia KP, Münchau A, Thompson PD, Houser M, Chauhan VS, Hutchinson M, et al. Generalised muscular weakness after botulinum toxin injections for dystonia: a report of three cases. J Neurol Neurosurg Psychiatry. 1999 Jul;67(1):90-3.

6 Bai L, Peng X, Liu Y, Sun Y, Wang X, Wang X, et al. Clinical analysis of 86 botulism cases caused by cosmetic injection of botulinum toxin (BoNT). Medicine (Baltimore). 2018 Aug;97(34):e10659.

7 Brunnschweiler H, Fuhr P, Steck AJ. P. Fuhr AJS. First clinical manifestation of myasthenia gravis after injection of botulinum toxin for cervical dystonia. Electroencephalogr Clin Neurophysiol. 1997;102(3):28-9.

8 Tarsy D, Bhattacharyya N, Borodic G. Myasthenia gravis after botulinum toxin A for Meige syndrome. Mov Disord. 2000 Jul;15(4):736-8.

9 Borodic G. Myasthenic crisis after botulinum toxin. Lancet. 1998 Dec;352(9143):1832.

10 Iwase T, Iwase C. Systemic effect of local and small-dose botulinum toxin injection to unmask subclinical myasthenia gravis. Graefes Arch Clin Exp Ophthalmol. 2006 Mar;244(3):415-6.

11 Dressler D. Subclinical myasthenia gravis causing increased sensitivity to botulinum toxin therapy. J Neural Transm (Vienna). 2010 Nov;117(11):1293-4. 
12 Glick ZR, Vaphiades MS, Northington ME. OnabotulinumtoxinA unmasking myasthenia gravis. Dermatol Surg. 2013 Mar;39(3 Pt 1):472-3.

13 Durmuș Tekçe H, Deymeer F, Oflazer Serdaroğlu P, Parman Y. Myasthenia gravis after botulinum toxin type A injection. Turkish J Neurol. 2016;22(3):143-4.

14 Chegini A. Therapeutic Plasma Exchange in a rare case myasthenic crisis after Botox injection [Internet]. Atheroscler Suppl. 2017 Nov;30:283-5.

15 Watts J, Brew B, Tisch S. Myasthenia gravis exacerbation with low dose ocular botulinum toxin for epiphoria [Internet]. J Clin Neurosci. 2015 Dec;22(12):1979-81.

16 Hara K, Matsuda A, Kitsukawa Y, Tanaka K, Nishizawa M, Tagawa A. Botulinum toxin treatment for blepharospasm associated with myasthenia gravis. Mov Disord. 2007 Jul;22(9):1363-4.

17 Fasano A, Bentivoglio AR, Ialongo T, Soleti F, Evoli A. Treatment with botulinum toxin in a patient with myasthenia gravis and cervical dystonia. Neurology. 2005 Jun;64(12):2155-6.

18 Emmerson J. Botulinum toxin for spasmodic torticollis in a patient with myasthenia gravis. Mov Disord. 1994 May;9(3):367-367.

19 Gonçalves MRR, Barbosa ER, Zambon AA, Marchiori PE. Treatment of cervical dystonia with botulinum toxin in a patient with myasthenia gravis. Arq Neuropsiquiatr. 1999;57(3 A):683-5. https://doi.org/10.1590/S0004-282X1999000400024.

20 Patel V, Elston J, Malhotra R. Prolonged effect of botulinum toxin-A treatment in patients with myasthenia gravis. J Clin Exp Ophthalmol. 2011;02(03):2155-6.

21 El-Heis S, Burke G, Gibb W, Ardern-Jones MR. Myaesthenia gravis exacerbation caused by axillary injection of botulinum toxin A for treatment of hyperhidrosis. Clin Exp Dermatol. 2017 Apr;42(3):357-9.

22 Crowner BE, Torres-Russotto D, Carter AR, Racette BA. Systemic weakness after therapeutic injections of botulinum toxin A: a case series and review of the literature. Clin Neuropharmacol. 2010 SepOct;33(5):243-7.

23 Cruz Martínez A, Anciones B, Ferrer MT, Díez Tejedor E, Pérez Conde MC, Bescansa E. Electrophysiologic study in benign human botulism type B. Muscle Nerve. 1985 Sep;8(7):580-5.

24 Cherington M. Electrophysiologic methods as an aid in diagnosis of botulism: a review. Muscle Nerve. 1982;5 9S:S28-9.

25 Cherington M. Botulism: update and review. Semin Neurol. 2004 Jun;24(2):155-63.

26 Howard JF Jr. Electrodiagnosis of disorders of neuromuscular transmission [Internet]. Phys Med Rehabil Clin N Am. 2013 Feb;24(1):169-92.

27 Sanders DB, Howard JF Jr. AAEE minimonograph \#25: single-fiber electromyography in myasthenia gravis. Muscle Nerve. 1986 Nov-Dec;9(9):809-19.

28 Lispi L, Leonardi L. Longitudinal neurophysiological assessment of intramuscular type-A botulin toxin in healthy humans. Neurol Sci. 2018 Feb;39(2):329-32. https://doi.org/10.1007/s10072-017-3191-3.

29 Leonardi L, Haggiag S, Petrucci A, Lispi L. Electrophysiological abnormalities in iatrogenic botulism: two case reports and review of the literature [Internet]. J Clin Neurosci. 2019 Feb;60(October):138-41.

30 Schiller HH, Stålberg E. Human botulism studied with single-fiber electromyography. Arch Neurol. 1978 Jun;35(6):346-9. 


\section{Case Reports in Neurology}

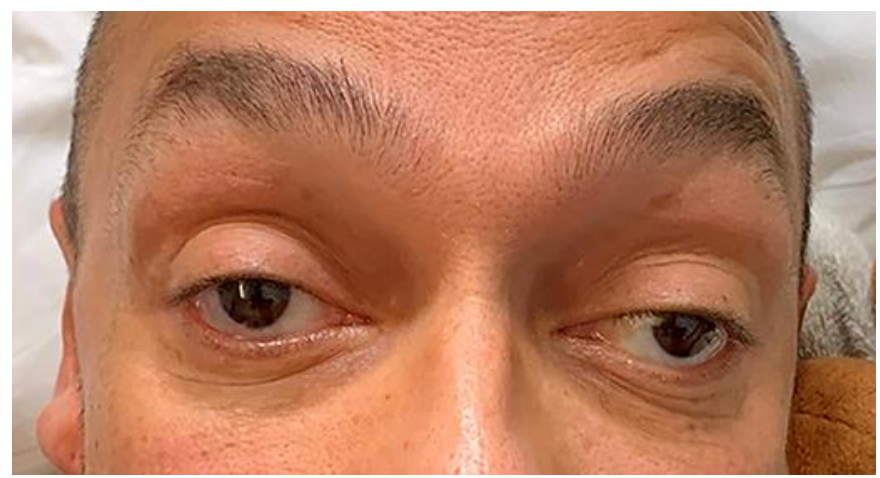

Fig. 1. A 43-year-old man presenting with constant bilateral eyelid ptosis and external ophthalmoplegia gradually worsening for 10 days.
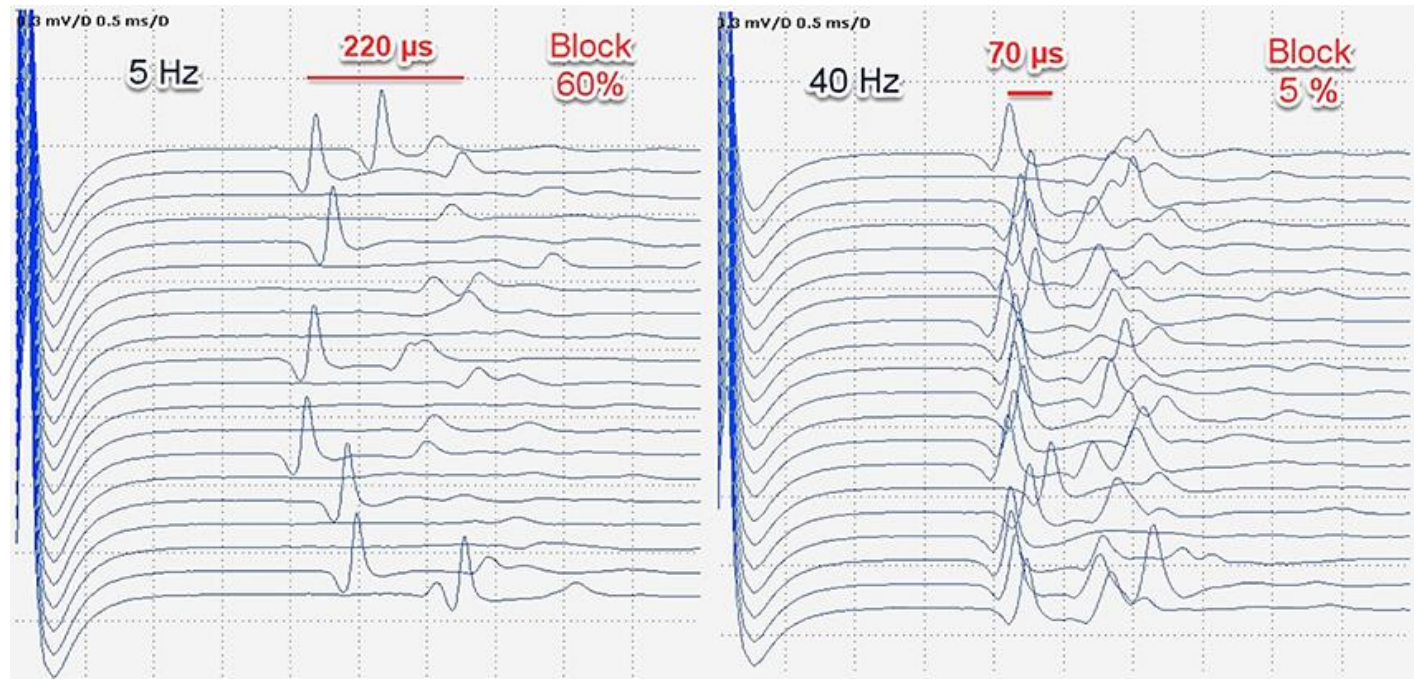

Fig. 2. SFEMG results of the left orbicularis oculi showing increased jitter with impulse blocking. In most neuromuscular junctions, mean jitter value and percentages of blocking decreases as the firing rate increases, which suggests presynaptic abnormalities. 


\section{Case Reports in Neurology}

Timmermans et al.: Cosmetic Injection of Botulinum Toxin Unmasking Subclinical

Myasthenia Gravis: A Case Report and Literature Review

Table 1. Comparison of patients with latent (unknown) MG unmasked by BoNT-A injection

\begin{tabular}{|c|c|c|c|c|c|c|}
\hline $\begin{array}{l}\text { First author, year } \\
\text { [Ref. No.] }\end{array}$ & Indication (age, sex) & Muscles injected & $\begin{array}{l}\text { BoNT-A dose } \\
\text { (type) }\end{array}$ & Prior BoNT-A injections & $\begin{array}{l}\text { Symptoms (latency/dura- } \\
\text { tion) }\end{array}$ & ENMG findings \\
\hline $\begin{array}{l}\text { Brunnschweiler, } \\
1997 \text { [7] }\end{array}$ & $\begin{array}{l}\text { Therapeutic: cervical } \\
\text { dystonia }(56, \mathrm{~F})\end{array}$ & Splenius capitis & $\begin{array}{l}12.5 \mathrm{ng} \\
\text { (Dysport) }\end{array}$ & Unspecified & $\begin{array}{l}\text { Dysphagia, chewing } \\
\text { muscles weakness, } \\
\text { dyspnea ( } 3 \text { weeks/unspeci- } \\
\text { fied) }\end{array}$ & $\begin{array}{l}\text { Decrement (\% un- } \\
\text { specified) in left del- } \\
\text { toideus and left "fa- } \\
\text { cial" }\end{array}$ \\
\hline $\begin{array}{l}\text { Borodic, } 1998[9] \\
\text { then Tarsy, } 2000 \\
{[8]}\end{array}$ & $\begin{array}{l}\text { Therapeutic: blepharo- } \\
\text { spasm, oromandibular } \\
\text { dyskinesia }(80, \mathrm{~F})\end{array}$ & $\begin{array}{l}\text { Orbicularis oculi, } \\
\text { lower facial }\end{array}$ & $120 \mathrm{U}$ (Botox) & $\begin{array}{l}18 \text { injections }(30-120 \mathrm{U}) \\
\text { over the past } 13 \text { years with } \\
\text { no complication }\end{array}$ & $\begin{array}{l}\text { Ptosis, diplopia, dysarthria, } \\
\text { dysphagia, generalized } \\
\text { weakness ( } 4 \text { days } / 5 \\
\text { months) }\end{array}$ & $\begin{array}{l}\text { Normal RNS } \\
\uparrow \text { jitter in posterior } \\
\text { cervical and upper ex- } \\
\text { tremity muscles }\end{array}$ \\
\hline Iwase, 2006 [10] & $\begin{array}{l}\text { Therapeutic: blepharo- } \\
\operatorname{spasm}(78, \mathrm{~F})\end{array}$ & Orbicularis oculi & $\begin{array}{l}40 \mathrm{U} \text { (unspeci- } \\
\text { fied) }\end{array}$ & $\begin{array}{l}2 \text { injections ( } 80 \mathrm{U} \text { and } 60 \mathrm{U} \text { ) } \\
1 \text { month and } 4 \text { months ear- } \\
\text { lier, with no complication }\end{array}$ & $\begin{array}{l}\text { Dysphagia, dysarthria, gen- } \\
\text { eralized weakness ( } 1 \text { week/ } \\
3 \text { months) }\end{array}$ & Unspecified \\
\hline $\begin{array}{l}\text { Dressler, } 2010 \\
{[11]}\end{array}$ & $\begin{array}{l}\text { Therapeutic: cervical } \\
\text { dystonia }(66, F)\end{array}$ & $\begin{array}{l}\text { Sternocleido-mas- } \\
\text { toideus, splenius } \\
\text { capitis, trapezius }\end{array}$ & $72 \mathrm{U}$ (Botox) & $\begin{array}{l}6 \text { injection series ( } 72- \\
180 \mathrm{U}) \text { with unspecified } \\
\text { timing }\end{array}$ & $\begin{array}{l}\text { Diplopia (1 month/unspeci- } \\
\text { fied) }\end{array}$ & $\begin{array}{l}\text { Unspecified (patho- } \\
\text { logical serial stimula- } \\
\text { tion) }\end{array}$ \\
\hline Glick, 2013 [12] & $\begin{array}{l}\text { Cosmetic: glabellar and } \\
\text { lateral cantal rhytids ( } 64 \text {, } \\
\text { F) }\end{array}$ & Periocular & $\begin{array}{l}58 \mathrm{U} \text { (unspeci- } \\
\text { fied) }\end{array}$ & $\begin{array}{l}1 \text { injection } 8 \text { months earlier } \\
(25 \mathrm{U}) \text {, with no complica- } \\
\text { tion }\end{array}$ & $\begin{array}{l}\text { Diplopia (1 week/unspeci- } \\
\text { fied) }\end{array}$ & Unspecified \\
\hline $\begin{array}{l}\text { Durmuş-Tekçe, } \\
2016 \text { [13] }\end{array}$ & $\begin{array}{l}\text { Therapeutic: oromandib- } \\
\text { ular dystonia }(80, \mathrm{~F})\end{array}$ & Hyoglossus & $\begin{array}{l}10 \text { MU (un- } \\
\text { specified) }\end{array}$ & $\begin{array}{l}8 \text { injections }(10 \mathrm{U}) \text {, every } 3 \\
\text { months before the occur- } \\
\text { rence, with no complication }\end{array}$ & $\begin{array}{l}\text { Ptosis, diplopia, dysphagia, } \\
\text { dyspnea, generalized weak- } \\
\text { ness ( } 10 \text { days } / 6 \text { months) }\end{array}$ & $\begin{array}{l}\text { RNS: dysfunction of } \\
\text { neuromuscular junc- } \\
\text { tion }\end{array}$ \\
\hline Chegini, 2017 [14] & $\begin{array}{l}\text { Cosmetic: facial rhytids } \\
(30, F)\end{array}$ & Unspecified & Unspecified & $\begin{array}{l}2 \text { injections during the pre- } \\
\text { ceding months, with no } \\
\text { complication }\end{array}$ & $\begin{array}{l}\text { Ptosis, diplopia, dysphagia, } \\
\text { dysarthria, dyspnea, gener- } \\
\text { alized weakness (the pre- } \\
\text { ceding months/unspecified) }\end{array}$ & $\begin{array}{l}\text { RNS: signs of pre- and } \\
\text { para-synaptic myopa- } \\
\text { thy }\end{array}$ \\
\hline $\begin{array}{l}\text { Timmermans (this } \\
\text { report) }\end{array}$ & $\begin{array}{l}\text { Cosmetic: glabellar and } \\
\text { lateral cantal rhytids }(43 \text {, } \\
\text { M) }\end{array}$ & Periocular & $\begin{array}{l}84 \text { U (Azza- } \\
\text { lure) }\end{array}$ & $\begin{array}{l}1 \text { injection } 2 \text { years earlier, } \\
\text { with no complication }\end{array}$ & $\begin{array}{l}\text { Ptosis, diplopia, dysphagia, } \\
\text { generalized weakness ( } 6 \\
\text { weeks/> } 6 \text { months) }\end{array}$ & $\begin{array}{l}\uparrow \text { jitter (orbicularis oc- } \\
\text { uli), decrement }\end{array}$ \\
\hline
\end{tabular}

